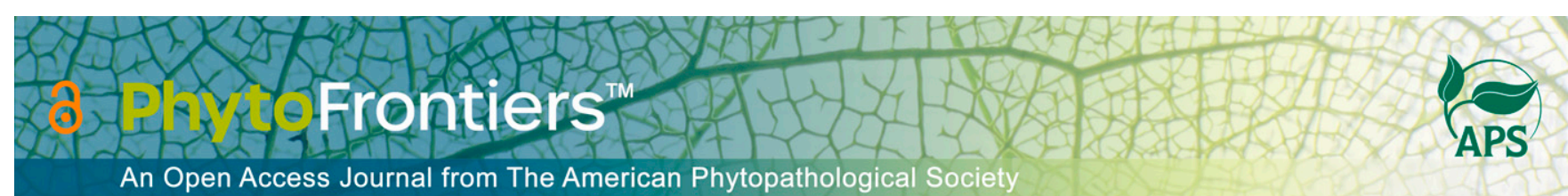

\title{
Research
}

\section{Role and In Vivo Localization of Fusarium oxysporum f. sp. strigae and Bacillus subtilis in an Integrated Striga hermonthica Biocontrol System}

\author{
Williams Oyifioda Anteyi(i) | Frank Rasche ${ }^{\dagger}$ |
}

Institute of Agricultural Sciences in the Tropics (Hans-Ruthenberg-Institute), University of Hohenheim, 70593 Stuttgart, Germany

\footnotetext{
${ }^{\dagger}$ Corresponding author: F. Rasche; frank.rasche@ uni-hohenheim.de
}

Accepted for publication 14 August 2020

\section{Funding}

Funding was provided by the German Federal Ministry for Economic Cooperation and Development (BMZ) and the German Academic Exchange Service (DAAD)

$\boldsymbol{e}$-Xtra: Five supplementary files are available online.

\begin{abstract}
To improve the efficiency of Striga hermonthica biological control in the context of an integrated biocontrol system, the role/impact of coinoculating the mycoherbicide Fusarium oxysporum f. sp. strigae (Fos) with a plant growth promoting rhizobacterium, Bacillus subtilis isolate GB03, on S. hermonthica attachment and sorghum biomass was investigated. Fos isolates (Foxy-2, FK3) and GB03, including Trichoderma viride (IMB12098 strain) as reference, were applied as single and combined treatments to $S$. hermonthica-infested rhizoboxes with sorghum as the host crop. In vivo localization/interaction of Fos and GB03 in S. hermonthica was monitored by fluorescent gene expression of transformed Fos and transformed GB03. Combined treatments of FK3 + GB03 and Foxy-2 + GB03 increased sorghum aboveground dry biomass $(P<0.05)$, but not IMB12098 $+\mathrm{GB} 03$. None of the combined treatments suppressed $S$. hermonthica attachment. Single treatments of FK3 and GB03 increased sorghum aboveground dry biomass $(P<0.05)$, but Foxy-2 and IMB12098 did not. Only FK3, of all single treatments, suppressed S. hermonthica attachment $(P<0.05)$. GB03 promoted sorghum yield when applied alone or combined with Fos $(P<0.05)$. Fos penetration of $S$. hermonthica through trichome entry was revealed. Although Fos, either as sporal (conidia) or vegetative form (mycelium), co-occupied common ecological niches with GB03 (they colocalize) in diseased S. hermonthica shoots, mainly in flavonoid-rich regions. Nevertheless, GB03 thwarted Fos suppressive activity against S. hermonthica attachment. In the given setup, coinoculation of Fos with GB03 presented no added advantage in suppressing the incidence of the sampled $S$. hermonthica.
\end{abstract}

Keywords: Striga hermonthica, Fusarium oxysporum f. sp. strigae, Foxy-2, FK3, Bacillus subtilis GB03, ecological niche, plant/microbe-microbe interactions 
The noxious, hemiparasitic witchweed Striga hermonthica (Delile) Benth. constitutes one of the most serious threats to cereal production, especially in tropical agroecosystems (Atera et al. 2011; Dawud 2017; Mounde et al. 2020; Teka 2014). Generally, $S$. hermonthica incidence is managed through four main approaches, which include traditional/cultural practices such as hand pulling, crop rotation, intercropping, trap/catch crop planting, and soil fertility improvement (nitrogen fertilization). The other $S$. hermonthica management strategies rely on chemical (weedicide, e.g., imazapyr), genetic ( $S$. hermonthicaresistant crop varieties), and biological (biological control agents [BCAs], e.g., fungi, bacteria, and certain insects) approaches. Each of these approaches alone is not completely efficient in combating S. hermonthica; thus, an integrated S. hermonthica management strategy is often recommended (Baiyegunhi et al. 2018; Berner et al. 1996; Mounde et al. 2020; Sibhatu 2016).

The mycoherbicidal effectiveness of the most renowned fungal BCA against $S$. hermonthica, which is Fusarium oxysporum f. sp. strigae (Fos), under both controlled and field conditions, has been well documented (Ciotola et al. 1995; Nzioki et al. 2016; Schaub et al. 2006). Fos has proven to inhibit S. hermonthica germination when applied pre-Striga seed conditioning period (Kroschel et al. 1996; Yonli et al. 2010) and/or to suppress $S$. hermonthica when applied at post-Striga attachment period (Abbasher et al. 1998; Marley et al. 1999). Fos attacks S. hermonthica plants by its hyphal colonization of xylem vessels at inception, followed by total vessel obstruction in mature (emerged) plants or complete tissue digestion of younger plantlets belowground, thereby killing S. hermonthica from wilting and tissue degradation (Ndambi et al. 2011). The Fos isolate Foxy-2 from Ghana has been widely reported for successful Striga spp. biocontrol management in West Africa (Abbasher et al. 1998; Elzein and Kroschel 2004). Similarly, FK3 is a Kenyan Fos isolate with proven antagonism against $S$. hermonthica in the East African region (Beed et al. 2013; Kangethe et al. 2016). A major drawback of Fos is the inconsistent effectiveness of its isolates, especially (but not limited to) M12-4, Foxy-2, and FK3, against diverse S. hermonthica populations of various origins (Avedi et al. 2014; Mounde et al. 2020; Venne et al. 2009). With respect to $S$. hermonthica, it has recently been shown that genomic variation in S. hermonthica is a superior determinant of the inconsistent effectiveness of Fos isolates (Foxy-2, FK3) against $S$. hermonthica, rather than the geographic origin of $S$. hermonthica populations (Anteyi and Rasche 2020). The inconsistency of Fos isolates in effectively controlling genetically diverse $S$. hermonthica populations lowers Fos reliability as an efficient mycoherbicide against $S$. hermonthica in various agro-ecological zones. Consequently, it hinders widespread acceptability of Fos as a BCA against $S$. hermonthica (Massart et al. 2015; Velivelli et al. 2014).

Comparably, plant growth promoting rhizobacteria (PGPR), particularly of the genera Pseudomonas sp., Azospirillum sp., and Bacillus sp., have been reported to ameliorate the menace of $S$. hermonthica, by reducing the seed germination, halting haustorial development/attachment, and delaying aboveground emergence (Ahonsi et al. 2002; Hassan et al. 2009; Mounde et al. 2015). PGPR are a heterogeneous group of rhizospherecolonizing beneficial bacteria that improve plant health and/or promote plant growth directly (biofertilization, phytostimulation, rhizoremediation) or indirectly (phytopathogen elimination, e.g., antibiosis, systemic resistance induction, competitive colonization for nutrients, and niche) (Backer et al. 2018; Lugtenberg and Kamilova 2009; Mariutto and Ongena 2015). In assessing the activity of four common PGPR strains in a S. hermonthicasorghum pathosystem, Mounde et al. (2015) verified Bacillus subtilis isolate GB03 as the most promising, compared with $B$. subtilis isolate Bsn5, B. amyloliquefaciens isolate FZB42, and Burkholderia phytofirmans isolate PsJN, in terms of inhibiting $S$. hermonthica germination with haustorial attachment and promoting the biomass of $S$. hermonthica-free sorghum plants.

Notwithstanding the advancements in S. hermonthica biocontrol research, related to the ecology and biocontrol potential of Fos and PGPR against Striga spp., it is still unknown if the combined application of these $S$. hermonthica-attacking agents will optimize $S$. hermonthica suppression. The goal is that technically a synergistic action of Fos attacking $S$. hermonthica and PGPR improving the host cereal growth can be achieved. It is also uncertain if the coinoculation of Fos and PGPR would be equally effective when applied either as pre-Striga seed conditioning or post-Striga attachment treatment. Furthermore, the localization/interaction of Fos and PGPR, in affected S. hermonthica, is unclear. Hence, the main research questions of this study were as follows: Will the coinoculation of Fos and PGPR improve the efficiency of combating $S$. hermonthica, while simultaneously promoting sorghum yield in a $S$. hermonthicasorghum pathosystem? Does the response pattern of $S$. hermonthica and sorghum differ, suggesting a preference for an application period (pre-Striga seed conditioning or post-Striga attachment) of the coinoculating Fos-PGPR treatments? How do Fos and PGPR localize/interact in S. hermonthica, when coinoculated in an integrated S. hermonthica biocontrol system? Answering these questions will foster the understanding of the functional role of the fungal-bacterial coinoculation in a $S$. hermonthica-sorghum pathosystem, the impact of the microbial treatments at different Striga stages/lifecycles (i.e., germination inhibition or attachment/emergence suppression), and the physiology of the host (i.e., S. hermonthica)-microbe (i.e., Fos, PGPR) interaction in an integrated $S$. hermonthica biocontrol system. This study hypothesized that the coinoculation of Fos and $B$. subtilis will jointly infect and co-occupy (colocalize) the diseased $S$. hermonthica, thereby optimizing $S$. hermonthica suppression by circumventing the limitations from both the inconsistent effectiveness of Fos isolates against $S$. hermonthica (Anteyi and Rasche 2020) and the instability of $S$. hermonthica germination inhibitor(s) produced by PGPR (Miché et al. 2000). It was expected that this would result to an improved growth promotion (biomass) of $S$. hermonthica-infected sorghum, because PGPR alone, as exemplified by B. subtilis, B. amyloliquefaciens, and B. phytofirmans, were shown not to improve the biomass of $S$. hermonthica-infected sorghum (Mounde et al. 2015). Our expectation for a synergistic interaction between Fos and PGPR was based on the compatibility of Fos with indigenous maize rhizosphere microbiota (Musyoki et al. 2016; Zimmermann et al. 2016a). Thus, in the framework of a $S$. hermonthica-sorghum pathosystem, the study aimed at examining: (i) the role/impact of Fos isolates (Foxy-2, FK3) with $B$. subtilis isolate GB03 coinoculation on $S$. hermonthica attachment and sorghum biomass, when applied as Striga preconditioning and Striga postattachment treatments, and (ii) the localization/interaction of the Fos-GB03 coinoculants in affected S. hermonthica plants.

\section{MATERIALS AND METHODS}

\section{Preparatory work}

Plant materials, microbial isolates/strains, and plasmids. S. hermonthica seeds, sampled from Sirinka, Ethiopia, were used as parasitic (model) plant in this study. S. hermonthica-susceptible sorghum (Sorghum bicolor L. Moench) cultivar PI563294 from 
Niger was used as host (model) crop. From our previous study (Anteyi and Rasche 2020), the sampled S. hermonthica population displayed selective susceptibility to FK3 but not to Foxy2. Also, the utilized sorghum cultivar exhibited susceptibility to diverse $S$. hermonthica populations from East and West Africa. B. subtilis isolate GB03, designated as 3A37 strain, was obtained from the Bacillus Genetic Stock Center, Ohio State University, Columbus, Ohio. It is noteworthy to state that the GB03 isolate was first identified as B. subtilis and later as B. amyloliquefaciens; however, due to its genome sequence, the strain $3 \mathrm{~A} 37$ has been reclassified as B. velezensis (D. R. Zeigler, personal communication). B. subtilis isolate GB03 was selected as a representative PGPR for this study, following its outstanding ability to inhibit $S$. hermonthica germination with haustorial attachment and promote the biomass of $S$. hermonthica-free sorghum plants in a $S$. hermonthica-sorghum pathosystem, compared with other PGPR (i.e., B. subtilis isolate Bsn5, B. amyloliquefaciens isolate FZB42, and B. phytofirmans isolate PsJN) (Mounde et al. 2015). Trichoderma viride strain IMB12098, DSM number 63065, was procured from the Leibniz-Institute DSMZ (Deutsche Sammlung von Mikroorganismen und Zellkulturen) $\mathrm{GmbH}$, Braunschweig, Germany. Fos isolates Foxy-2 and FK3 were obtained as $20 \%$ glycerol stocks from a $-80^{\circ} \mathrm{C}$ microbial cell bank at the Institute of Agricultural Sciences in the Tropics, University of Hohenheim, Germany.

pFPL-Ch (61647) and pFPL-Rh (61649) plasmids were procured from Addgene (2019) repository. Development of these plasmids were described by Gong et al. (2015). Both plasmids contain antibiotic resistance genes for chloramphenicol, kanamycin, and hygromycin (as selectable markers). pFPL-Ch contained a 720-bp gene insert, enhanced cyan fluorescent protein, for cyan fluorescence expression. A 678-bp gene insert, monomeric red fluorescent protein in pFPL-Rh, is responsible for red fluorescence expression (Fig. 1).

Seed sterilization. Surface sterilization of S. hermonthica and sorghum seeds was performed according to the method of Anteyi and Rasche (2020). For S. hermonthica, the seeds were first submerged in a mixture of $5 \%(\mathrm{v} / \mathrm{v})$ sodium hypochlorite (containing 12\% chlorine) (Carl Roth GmbH, Karlsruhe, Germany) and $0.02 \%$ (v/v) Tween 20 (Carl Roth $\mathrm{GmbH}$ ). Then, sonication for $3 \mathrm{~min}$ (Bandelin Sonopuls $\mathrm{GmbH}$, Berlin,
Germany) was followed by five to six rinses with double-distilled water $\left(\mathrm{ddH}_{2} \mathrm{O}\right)$. Surface sterilization of sorghum seeds was by immersing in $70 \%$ ethanol for $2 \mathrm{~min}$, followed by rinsing thrice with $\mathrm{ddH}_{2} \mathrm{O}$. Then, seeds were submerged in a blend of $1 \%$ sodium hypochlorite and $0.02 \%(\mathrm{v} / \mathrm{v})$ Tween 20 for $3 \mathrm{~min}$; finally, they were rinsed five to six times with $\mathrm{ddH}_{2} \mathrm{O}$. Glass fiber filter papers ( $90 \mathrm{~mm}$, Macherey-Nagel $\mathrm{GmbH}$, Düren, Germany) were oven sterilized for $48 \mathrm{~h}$ at $65^{\circ} \mathrm{C}$ and then placed under a laminar flow hood with UV for $2 \mathrm{~h}$. Surface-sterilized $S$. hermonthica and sorghum seeds were separately air dried on the sterilized glass fiber filter papers under a laminar flow hood without UV for $48 \mathrm{~h}$.

Germination percentage of surface-sterilized S. hermonthica seeds. Approximately 200 surface-sterilized S. hermonthica seeds were spread on an $8-\mathrm{mm}$ punched disc of sterilized glass fiber filter papers. Six discs (replicates) carrying the $S$. hermonthica seeds were placed on two layers of 90-mm sterilized glass fiber filter papers, within a 90-mm Petri dish. Six milliliters of $\mathrm{ddH}_{2} \mathrm{O}$ was added to the Petri dish. Then, the Petri dish was covered, sealed with Parafilm, and incubated in a dark chamber at $30^{\circ} \mathrm{C}$ for 14 days, for preconditioning. Thereafter, the discs (with preconditioned seeds) were transferred onto a fresh glass fiber filter paper, within a Petri dish, and $3 \mathrm{ml}$ of a 0.1 -ppm synthetic strigolactone analog, rac-GR24 (Chiralix B.V., Nijmegen, Netherlands) was applied to the Petri dish. The setup was reincubated at $30^{\circ} \mathrm{C}$ for $24 \mathrm{~h}$ for germination. Afterward, germinated seeds were counted under a binocular microscope (Zeiss Stemi 2000-C Stereomicroscope, Carl Zeiss Microscopy GmbH, Jena, Germany), coupled with the Zeiss AxioCam HRc (Carl Zeiss Light Microscopy, Göttingen, Germany). This germination assay was done in two experimental repetitions.

\section{Fos-GB03 coinoculation study}

Pre-Striga seed conditioning treatment application. Microbial culturing and inocula concentrations. Mycelial suspensions of Foxy-2 and FK3, including IMB12098, were separately prepared by flooding the surface of their 2-week-old actively growing potato dextrose agar (PDA) (Carl Roth $\mathrm{GmbH}$ ) cultures in $90-\mathrm{mm}$ Petri dishes, each with $10 \mathrm{ml}$ of $25 \%$ potato dextrose broth (PDB) (Carl Roth GmbH). Then, they were left to stand for
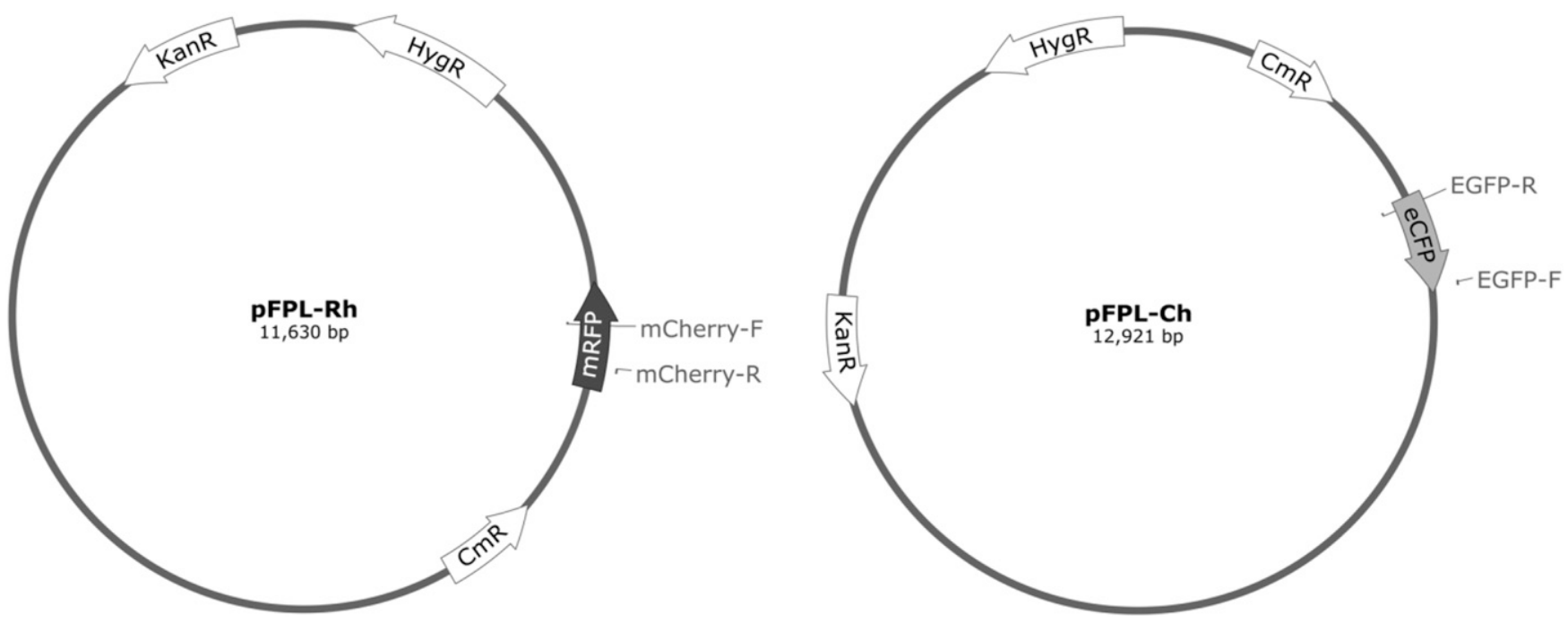

FIGURE 1

Schematic plasmid maps of pFPL-Rh and pFPL-Ch with fluorescent proteins, specific primers used, and antibiotic resistance. CmR = chloramphenicol; KanR = kanamycin; HygR = hygromycin; eCFP = enhanced cyan fluorescent protein; and mRFP = monomeric red fluorescent protein. Plasmid maps were created with SnapGene Viewer 5.0.7. 
$30 \mathrm{~min}$, before gently scraping the mycelial mass into sterile flasks containing 2 liters of $25 \%$ PDB. For colony growth, the flasks were loosely covered with their lids and placed in a dark incubating shaker for 15 days at $65 \mathrm{rpm}$ and $28^{\circ} \mathrm{C}$. A colony of GB03 was separately transferred from overnight Luria-Bertani (LB) agar cultures into sterile flasks containing 2 liters of $15 \% \mathrm{LB}$ broth. The loosely covered flasks were placed in a dark incubating shaker for 4 days at $80 \mathrm{rpm}$ and $35^{\circ} \mathrm{C}$.

Inocula concentrations in colony forming units per milliliter $(\mathrm{CFU} / \mathrm{ml})$ were determined from six replicates of each microbial inoculum: Foxy-2 and FK3, $10^{4}$ to $10^{5}$; GB03, $10^{6}$ to $10^{7}$; and IMB12098, 10 ${ }^{7}$. The prepared fungal and bacterial inocula were subsequently used as pre-Striga seed conditioning planting treatments.

Planting trials. Sixty grams of sterilized modular seed substrate (Klasmann-Deilmann GmbH, Geeste, Germany) was filled into polyvinyl chloride rhizoboxes of dimensions $20 \times 5 \times$ $2 \mathrm{~cm}$. Then, $60 \mathrm{mg}$ of surface-sterilized $S$. hermonthica seeds were sown $5 \mathrm{~cm}$ below the substrate surface, and the front side of each rhizobox was covered with Plexiglas. Sixty milliliters of $\mathrm{ddH}_{2} \mathrm{O}$ or the prepared microbial inocula (as single or combined fungi + bacteria coinoculation) were applied to each rhizobox as treatments. For rhizoboxes containing combined fungi + bacteria treatments, $30 \mathrm{ml}$ of each microbial inoculum was added. Also, $T$. viride (IMB12098 strain) was introduced among the planting treatments to serve as a check BCA treatment, because $T$. viride was reported to completely inhibit $S$. hermonthica seed germination at $10^{6}$ spores $/ \mathrm{ml}$ inoculum concentration (Hassan et al. 2013). Hence, treatments included (i) $\mathrm{ddH}_{2} \mathrm{O}$ without $S$. hermonthica (negative control); (ii) $S$. hermonthica with $\mathrm{ddH}_{2} \mathrm{O}$ (positive control); (iii) $S$. hermonthica with FK3 and GB03 (Striga + FK3 + GB03); (iv) S. hermonthica with Foxy-2 and GB03 (Striga + Foxy-2 + GB03); (v) S. hermonthica with IMB12098 and GB03 (Striga + IMB12098 + GB03); (vi) $S$. hermonthica with GB03 (Striga + GB03); (vii) S. hermonthica with FK3 (Striga + FK3); (viii) S. hermonthica with Foxy-2 (Striga + Foxy-2); (ix) S. hermonthica with IMB12098 (Striga + IMB12098). The setup was incubated at $30^{\circ} \mathrm{C}$ for 10 days in a dark climate chamber (Percival Intellus Environmental Controller, EA-75HIL, Perry, IA) for S. hermonthica seed preconditioning. The experiment was set up in a randomized complete block design, with three replications for each treatment.

Thereafter, a single sorghum seed was sown in every rhizobox, and climate chambers were set at 31 and $27^{\circ} \mathrm{C}$, for day and night temperatures, respectively. Light of mean illuminance 46,000 lx was available for $12 \mathrm{~h}$ (as day), but without light as night. Plants were irrigated twice per week, first with $\mathrm{ddH}_{2} \mathrm{O}$ and then with nutrient solution comprising a blend of $0.2 \%$ (v/v) Wuxal

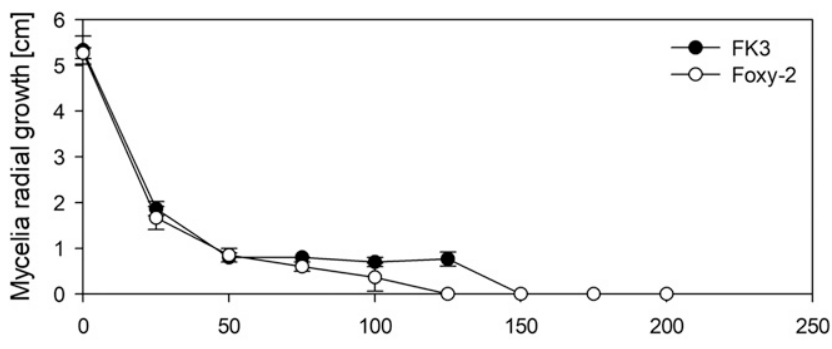

Hygromycin-B concentration supplemented in PDA $\left[\mu \mathrm{g} \mathrm{ml}^{-1}\right]$

FIGURE 2

Hygromycin B sensitivity test to determine mycelial growth inhibition in wild-type FK3 and wild-type Foxy-2. Error bars indicate standard deviation. PDA = potato dextrose agar. universal liquid fertilizer (Aglukon Spezialdünger $\mathrm{GmbH}$, Düsseldorf, Germany) and Yoshida nutrient solution (Yoshida et al. 1976) in a ratio of three parts Wuxal to two parts Yoshida. The planting trials were done in two experimental repetitions, with a 5-week growing period for each trial.

Post-Striga attachment treatment application and localization study. Antimycotic and antibiotic sensitivity determination. Freshly prepared, molten PDA was supplemented with hygromycin B (Carl Roth $\mathrm{GmbH})$ at 0, 25, 50, 75, 100, 125, 150, 175, and $200 \mu \mathrm{g} / \mathrm{ml}$. An 8-mm agar plug from actively growing Foxy-2 and FK3 mycelia was each transferred to $90-\mathrm{mm}$ Petri dishes containing the solidified media. The experiment was set up in three replications. The cultures were incubated in the dark for 7 days at $28^{\circ} \mathrm{C}$, followed by determination of mycelial radial growth. Hygromycin B concentration of 125 and $150 \mu \mathrm{g} / \mathrm{ml}$ completely inhibited mycelial growth of wild-type Foxy-2 and FK3, respectively (Fig. 2). Sensitivity assay revealed that $200 \mu \mathrm{g} / \mathrm{ml}$ of hygromycin B completely inhibited wild-type GB03. For kanamycin sensitivity, $50 \mu \mathrm{g} / \mathrm{ml}$ was used (http://www.addgene.org/ mol-bio-reference/). Hence, growth medium supplemented with $200 \mu \mathrm{g} / \mathrm{ml}$ of hygromycin B and $50 \mu \mathrm{g} / \mathrm{ml}$ of kanamycin sulfate (Carl Roth $\mathrm{GmbH}$ ), hereafter abbreviated as Hyg-B/Kan, was adopted for selectively screening transformed Fos or transformed GB03.

Plasmid DNA isolation. Using the Invisorb Spin Plasmid Mini Two (Stratec Molecular GmbH, Berlin, Germany), plasmid DNA (pDNA) was isolated from the bacteria containing the plasmids (i.e., pFPL-Ch and pFPL-Rh) after culturing a single colony of the bacteria in 15-ml tubes containing $2 \mathrm{ml}$ of $15 \% \mathrm{LB}$ broth (Carl Roth $\mathrm{GmbH}$ ) with Hyg-B/Kan for $15 \mathrm{~h}$ at $100 \mathrm{rpm}$ and $37^{\circ} \mathrm{C}$ in a dark shaker. Diagnostic restriction digestion with HindIII, FspI, KpnI, and AflII (New England Biolabs GmbH, Frankfurt am Main, Germany) was performed to verify the plasmids. Digested DNA products confirmed the plasmids, as shown by $1.5 \%$ agarose gel electrophoresis (see Supplementary File S1).

Fos transformation mediated by polyethylene glycol (PEG). The procedure for PEG-mediated transformation of Fos was modified from the protocol for PEG-mediated transformation of $F$. oxysporum f. sp. conglutinans (Zhang et al. 2014). The detailed methodology is given in Supplementary File S2.

GB03 transformation ("mixed salts" mediated). The protocol for GB03 transformation was adapted from the International Genetically Engineered Machine (iGEM 2014) (Ludwig Maximilian University of Munich, Germany), but with minor adjustments. The detailed methodology is provided in Supplementary File S3.

Screening and verification of Fos and GB03 transformants. Fos and GB03 transformants were screened by their ability to grow on antibiotic-supplemented selective medium, in which wild-type Fos and GB03 were unable to grow (Fig. 3). The mycelia of transformed Fos and a colony of transformed GB03 were also screened for fluorescence expression using the Zeiss Axioskop-2 Plus Upright Fluorescence Microscope (Carl Zeiss Microscopy $\mathrm{GmbH}$ ), and AxioVision SE64 Rel. 4.8 software (Jülich GmbH, Bonn, Germany). Red fluorescence expression in transformed Fos was detected at $546 \mathrm{~nm}$ (excitation) and $580 \mathrm{~nm}$ (emission), whereas cyan fluorescence expression in transformed GB03 was detected at $475 \mathrm{~nm}$ (excitation) and $500 \mathrm{~nm}$ (emission) (Fig. 4).

To verify successful fluorescence gene integration in Fos and GB03 transformants, total genomic DNA (gDNA) was extracted from a 100-mg biomass of Fos hyphae and GB03 cellular pellets transformants (Fast DNA spin kit, MP Biomedicals, LLC). Primer sequences in the fluorescent gene inserts of the plasmids 
were identified with SnapGene Viewer 5.0.7 (GSL Biotech, https://www.snapgene.com/): mCherry primers for pFPL-Rh (mCherry-F, 5'-CCCCGTAATGCAGAAGAAGA-3'; mCherry-R, $3^{\prime}$-TTGGTCACCTTCAGCTTGG-5') and EGFP primers for pFPL-Ch (EGFP-F, 5'-CATGGTCCTGCTGGAGTTCGTG-3'; EGFP-R, 3'-CGTCGCCGTCCAGCTCGACCAG-5'). Polymerase chain reaction (PCR) was done by a $50-\mu 1$ reaction system, consisting of template DNA (pDNA, $5 \mathrm{ng}$; gDNA, $200 \mathrm{ng}$ ), 10× PCR buffer, $50 \mathrm{mM} \mathrm{MgCl}$, $10 \mathrm{mM}$ dNTPs, $20 \mu \mathrm{M}$ forward and reverse primers for both mCherry and EGFP primers (biomers.net $\mathrm{GmbH}$, Ulm, Germany), and 2.5 U of Accuzyme DNA Polymerase (Bioline $\mathrm{GmbH}$, Luckenwalde, Germany). PCR conditions with mCherry primers included initial denaturation at $95^{\circ} \mathrm{C}$ for $3 \mathrm{~min}$, followed by 30 cycles at $95^{\circ} \mathrm{C}$ for $15 \mathrm{~s}, 55^{\circ} \mathrm{C}$ for $15 \mathrm{~s}$, and $72^{\circ} \mathrm{C}$ for $30 \mathrm{~s}$. Reaction was completed with a final extension at $72^{\circ} \mathrm{C}$ for $4 \mathrm{~min}$. With EGFP primers, PCR conditions were initial denaturation at $95^{\circ} \mathrm{C}$ for $3 \mathrm{~min}$, then 30 cycles at $95^{\circ} \mathrm{C}$ for $15 \mathrm{~s}, 60^{\circ} \mathrm{C}$ for $15 \mathrm{~s}, 72^{\circ} \mathrm{C}$ for $45 \mathrm{~s}$, and a final elongation at $72^{\circ} \mathrm{C}$ for $4 \mathrm{~min}$.

Microbial transformants culturing and inocula concentrations. Preparation of transformed Fos and GB03 microbial cultures and determination of their inocula concentrations in $\mathrm{CFU} / \mathrm{ml}$ were similar to the procedures described above for their corresponding wild-type microbial treatment cultures. Inocula concentrations of the transformed microbial cultures in $\mathrm{CFU} / \mathrm{ml}$ were $10^{5}$ to $10^{6}$ for transformed Foxy-2 and transformed FK3 and $10^{6}$ for transformed GB03. The prepared transformed microbial inocula, together with their wild types, were used as post-Striga attachment planting treatments.

Planting trials and localization study. The planting trials made use of wild-type microbial treatments to study the impact of the post-Striga attachment treatment application on the sorghum-S. hermonthica pathosystem. It utilized the transformed microbial treatments to examine the localization/interaction of Fos and GB03 in affected S. hermonthica, to give further insight into the post-Striga attachment treatment application of FosGB03. Planting for the post-Striga attachment treatment application study followed similar technical steps, experimental
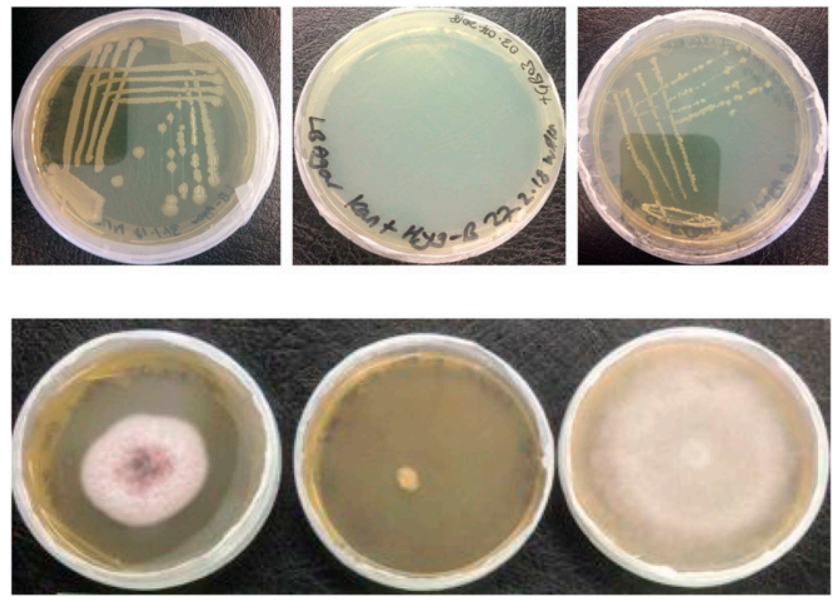

FIGURE 3

Wild-type GB03 growing on Luria-Bertani (LB) agar (top left). Wildtype GB03 unable to grow on LB agar supplemented with $200 \mu \mathrm{g} /$ $\mathrm{ml}$ of hygromycin B and $50 \mu \mathrm{g} / \mathrm{ml}$ of kanamycin sulfate (Hyg-B/ Kan) (top center). Transformed GB03 growing on LB agar supplemented with Hyg-B/Kan (top right). Wild-type FK3 growing on potato dextrose agar (PDA) (bottom left). Wild-type FK3 unable to grow on PDA supplemented with $\mathrm{Hyg}-\mathrm{B} / \mathrm{Kan}$ (bottom center). Transformed FK3 growing on PDA supplemented with Hyg-B/Kan (bottom right). conditions, setup, and iterations as described for the pre-Striga seed conditioning treatment application study (see above). However, here, treatments were applied following $S$. hermonthica attachment to sorghum root, precisely 3 weeks after sowing sorghum. This timing was also ascertained from the average period for visible $S$. hermonthica attachment.

Sixty milliliters of the treatments, that is, $\mathrm{ddH}_{2} \mathrm{O}$ or the prepared microbial inocula (as single or combined fungi + bacteria coinoculation, in separate wild-type and transformed setups) was directly applied on the substrate surface and/or on emerged (aboveground) S. hermonthica in each rhizobox. Similarly, in rhizoboxes for combined fungi + bacteria treatments, $30 \mathrm{ml}$ of each microbial inoculum was added. Thus, treatments were (i) $\mathrm{ddH}_{2} \mathrm{O}$ without $S$. hermonthica (negative control); (ii) $\mathrm{dd}_{2} \mathrm{O}$ with $S$. hermonthica (positive control); (iii) S. hermonthica with wild-type FK3 and wild-type GB03 (Striga + FK3 + GB03); (iv) S. hermonthica with wild-type Foxy-2 and wild-type GB03 (Striga + Foxy-2 + GB03); (v) S. hermonthica with wild-type GB03 (Striga + GB03); (vi) S. hermonthica with wild-type FK3 (Striga + FK3); (vii) S. hermonthica with wild-type Foxy-2 $($ Striga + Foxy-2); (viii) S. hermonthica with transformed FK3 and transformed GB03 (Striga + FK3[T] + GB03[T]); (ix) $S$. hermonthica with transformed Foxy-2 and transformed GB03 $($ Striga + Foxy-2[T] + GB03[T]); (x) S. hermonthica with transformed GB03 (Striga + GB03[T]); (xi) S. hermonthica with transformed FK3 (Striga + FK3[T]); and (xii) S. hermonthica with transformed Foxy-2 (Striga + Foxy-2[T]). Planting period was for 7 weeks to allow for adequate microbial colonization of sorghum for microscopic analysis.

In vivo localization analysis (microscopy and PCR). Localization of Fos and GB03 in infected and diseased $S$. hermonthica was studied through fluorescence expression by transformed Fos and transformed GB03 in infected S. hermonthica plants. Histological sections of $S$. hermonthica belowground and aboveground shoots and leaves were analyzed by digital imaging, using Zen software (version 2010) with a Zeiss laser scanning microscope (Carl Zeiss Microscopy GmbH). The presence of Fos and GB03 transformants in S. hermonthica was further confirmed by PCR, using primers specific to the fluorescence gene regions in the plasmids (see above).

\section{Plant data collection and biostatistical analysis}

The total counts of attached S. hermonthica, belowground and aboveground, in each rhizobox were recorded. Sorghum aboveground biomass was harvested and oven dried at $65^{\circ} \mathrm{C}$ for 10 days, and dry mass was determined. Quantitative data of the
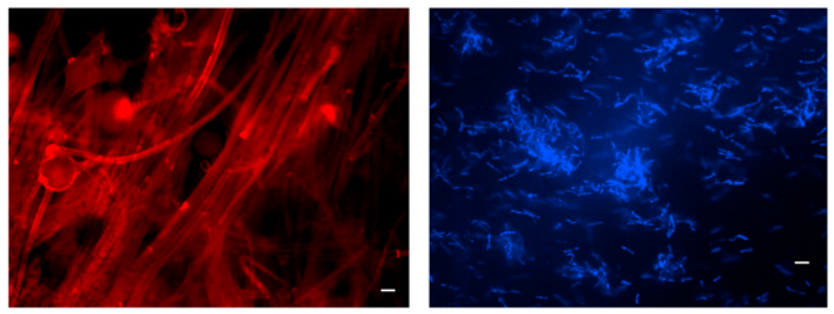

FIGURE 4

Mycelia of transformed FK3 from potato dextrose agar supplemented with $200 \mu \mathrm{g} / \mathrm{ml}$ of hygromycin B and $50 \mu \mathrm{g} / \mathrm{ml}$ of kanamycin sulfate (Hyg-B/Kan) expressing red fluorescence (left). Short chains of transformed GB03 from Luria-Bertani agar supplemented with $\mathrm{Hyg}-\mathrm{B} / \mathrm{Kan}$ expressing cyan fluorescence (right). Scale bars $=50 \mu \mathrm{m}$. 
attached S. hermonthica and the sorghum aboveground dry biomass were tested by analysis of variance (ANOVA) and post hoc analysis by Tukey's range test. For purposes of clarity and easy comparison between the $S$. hermonthica attachment and sorghum aboveground dry biomass, graphical presentation of Tukey's range test for the mean data values was standardized (as percentage), relative to the positive control (without altering the output of the analyses).

Calculation by Pearson correlation coefficient was used to corroborate the negative correlation between the sampled $S$. hermonthica attachment and sorghum aboveground dry biomass (of the adopted sorghum cultivar) in the presence of microbial treatments. This was because from repeated preliminary studies, in the absence of microbial treatments, a strong negative correlation $(r=-0.98, P<0.0001)$ was calculated between the sampled $S$. hermonthica attachment and the aboveground dry biomass of the same sorghum cultivar (see Supplementary File S4). Evaluation of the impact of Fos and GB03 on S. hermonthica, when the microbial treatments were applied at postStriga attachment, was indirectly determined from the sorghum aboveground dry biomass. This was a reliable estimator for the microbial treatments' effects on the already attached $S$. hermonthica plants. This indirect estimation was also supported by the stable and negative correlation between the $S$. hermonthica attachment and the sorghum aboveground dry biomass. All statistical analyses were carried out using SAS 9.4 (SAS Institute, Cary, NC).

\section{RESULTS}

\section{Role/impact of Fos-GB03 coinoculation on S. hermonthica attachment and sorghum biomass}

Pre-Striga seed conditioning treatment application. The surface-sterilized $S$. hermonthica seeds had a mean percentage germination of $55 \%$. ANOVA revealed that pre-Striga seed conditioning treatment application had different effects on $S$. hermonthica attachment $(P<0.01)$ and sorghum aboveground dry biomass $(P<0.01)$. Combined treatments of FK3 + GB03 and Foxy-2 + GB03 increased sorghum aboveground dry biomass $(P<0.05)$, but IMB12098 + GB03 did not. Neither FK3 + GB03, Foxy-2 + GB03, nor IMB12098 + GB03 reduced $S$.

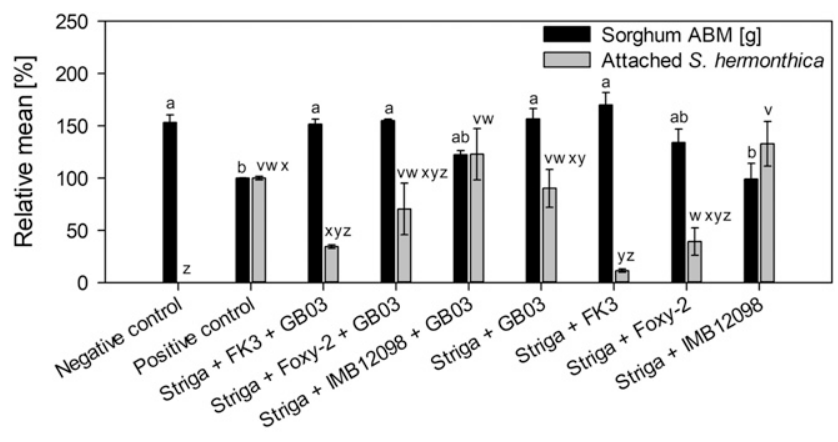

Treatments

FIGURE 5

Tukey's range test for relative mean values of sorghum aboveground dry biomass (sorghum ABM) and Striga hermonthica attachment responses to pre-Striga seed conditioning treatment application. Negative control $=\mathrm{ddH}_{2} \mathrm{O}$ without $\mathrm{S}$. hermonthica. Positive control $=S$. hermonthica with $\mathrm{ddH}_{2} \mathrm{O}$. Bars having at least a letter in common represent treatments means that are not significantly different $(\alpha=0.05)$. Error bars indicate standard error. hermonthica attachment $(P>0.05)$. FK3 and GB03, applied as single treatments, increased sorghum aboveground dry biomass $(P<0.05)$. Single treatments of Foxy-2 and IMB12098 did not increase sorghum aboveground dry biomass $(P>0.05)$. FK3 suppressed $S$. hermonthica attachment $(P<0.05)$, an effect not revealed for GB03, Foxy-2, and IMB12098. (Fig. 5). GB03 applied as a single treatment was ineffective in suppressing the attachment of the sampled S. hermonthica, and it thwarted Fos suppressive activity against $S$. hermonthica attachment. Nevertheless, GB03 promoted sorghum yield, either when applied alone or in combination with Fos $(P<0.05)$. This indicated that Fos (FK3) was primarily responsible for causing disease and death to $S$. hermonthica, whereas B. subtilis (GB03) was responsible for relieving the menace of $S$. hermonthica on sorghum productivity by promoting sorghum growth. In the presence of the microbial treatments, sorghum aboveground dry biomass showed a strong negative correlation to $S$. hermonthica attachment $(P<0.05)$ (Fig. 6).

Post-Striga attachment treatment application. Similarly, post-Striga attachment microbial treatment application had a different effect on sorghum aboveground dry biomass $(P<$ $0.0001)$. In both wild-type or transformed microbial treatments, all Fos-GB03 combined treatments and single treatments of FK3 and GB03 improved sorghum aboveground dry biomass $(P<$ 0.05). However, with single treatments of Foxy-2, the sorghum aboveground dry biomass was not higher than the positive control $(P>0.05)$ (Fig. 7).

\section{Localization/interaction of Fos and B. subtilis in emerged S. hermonthica}

Morphologically, S. hermonthica from the positive control (i.e., treated with $\mathrm{ddH}_{2} \mathrm{O}$ ) showed no infection signs (Fig. 8A). Also, microscopic examination of the positive control showed healthy $S$. hermonthica leaf, phloem, and xylem tissues (Fig. 8B to D). For S. hermonthica treated with Fos (particularly FK3), infection of $S$. hermonthica through trichome entry was revealed (Fig. 8E). Fos infection and pathological damage of emerged (aboveground) $S$. hermonthica originated (and was more intense) on $S$. hermonthica shoots, before spreading throughout the entire plant structure (Fig. 8F and G). Following Fos (FK3) colonization of $S$. hermonthica, Fos degraded $S$. hermonthica tissues until plant death (Fig. 8H). Then, it thrived on the dead and decaying $S$. hermonthica matter (this was also substantiated by the persistent fluorescence expression) (Fig. 8I). This necrotrophic attribute of FK3 was not displayed by GB03. Cyan fluorescence detection at 475 to $500 \mathrm{~nm}$ indicated high GB03

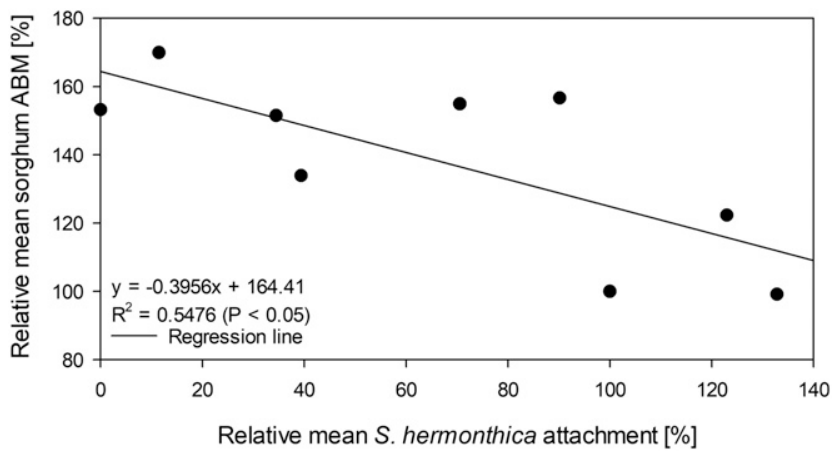

FIGURE 6

Correlation and regression between relative mean values of sorghum aboveground dry biomass (sorghum ABM) and Striga hermonthica attachment in presence of microbial treatments. 
localization in flavonoid-rich spots of $S$. hermonthica shoot tissue (Fig. 8J). Fos, either as sporal (conidia) or vegetative form (mycelium), infected and co-occupied common ecological niches with GB03 in diseased S. hermonthica shoots (i.e., both Fos and GB03 colocalized degrading shoot tissue of infected $S$. hermonthica) (Fig. 8K and L). The interaction of Fos and GB03 (colocalization) was not distinctly observed in S. hermonthica leaves. Colocalization of Fos and GB03 in the infected S. hermonthica was further confirmed by PCR of fluorescent genes carried by the transformed microbial inoculants, from planting trials of the post-Striga attachment treatment application (see Supplementary File S5).

\section{DISCUSSION}

\section{FK3 controlled S. hermonthica attachment, and it infected S. hermonthica through trichome entry when applied post-Striga attachment}

Among the microbial treatments, only FK3 effectively controlled the attachment of the sampled $S$. hermonthica. In assessing the variable susceptibility pattern of genetically diverse $S$. hermonthica populations from East and West Africa to Fos isolates, similarly sampled $S$. hermonthica from Sirinka, Ethiopia, displayed significant susceptibility to FK3 but not to Foxy-2 (Anteyi and Rasche 2020). This implied that the susceptibility pattern of a $S$. hermonthica population to Fos isolates, thus far, is a stable feature that is primarily explained by the innate attributes (genetic) of $S$. hermonthica. It therefore explains a finding from this study, as to why the effectiveness of a Fos isolate against $S$. hermonthica was not altered by the fungal treatment application period during planting. This was shown by the significant susceptibility of the sampled $S$. hermonthica to FK3 but not to Foxy-2, either when the microbial treatments were applied pre-Striga seed conditioning or post-Striga attachment. Hence, this corroborated the narratives that Fos mycoherbicidal action against $S$. hermonthica may occur through chemical (i.e., release of certain metabolites that inhibit $S$. hermonthica germination and/or attack young $S$. hermonthica plantlets belowground, before haustorial attachment) as well as mechanical (i.e., epidermal penetration of emerged or mature $S$. hermonthica shoot, especially through natural opening or wounds) modes (Abbasher and Sauerborn 1992; Yonli et al. 2010). For instance, Fusarium spp. have been reported to produce chemical substances (e.g., fusaric acid, 9,10-dehydrofusaric acid, trichothecenes, and $\beta$-lactones) that inhibit $S$. hermonthica seed germination (Sugimoto et al. 2002; Xiang et al. 2017; Zonno et al. 1996). Likewise, the successful post-Striga attachment foliar application of Fos isolate PSM-197 against S. hermonthica has been earlier noted (Marley et al. 1999).

Fluorescence microscopic analysis revealed that when the microbial treatments were applied post-Striga attachment, trichome entry was among the mechanical means by which Fos (FK3) penetrated $S$. hermonthica. This finding contrasted the acknowledged indirect mode by which Fos infects $S$. hermonthica, whereby Fos hyphae penetrate $S$. hermonthica through the "sorghum central cylinder-S. hermonthica haustorial" connecting tissues within sorghum root, without causing any known pathological damage to sorghum (Elzein et al. 2010; Ndambi et al. 2011). Fos infection of $S$. hermonthica by trichome entry is possible, because $S$. hermonthica shoots and leaves are largely covered with unique trichomes (CABI 2019). Apart from the primary roles of trichomes, which include protection, water/ moisture absorption, storage or secretion of specialized metabolic compounds, and elimination of excess toxic substances
(Huchelmann et al. 2017; Werker 2000), they are also host sites for plant relationships with endophytic fungi. Injured trichomes give rise to open bases or stalks, which can serve as favorable entry points for phytopathogens, thereby encouraging fungal infection (penetration and colonization). Thus, trichomes serve as an uncommon fungal niche (Andargie and Li 2016; Calo et al. 2006; Kim 2019).

FK3 colonized, degraded, killed, and thrived on the dead tissue of $S$. hermonthica. This is a typical necrotrophic lifestyle of $F$. oxysporum (Moore et al. 2018). The necrotrophic feature of Fos, together with its chlamydospore-forming ability, facilitates its existence as a soil-borne phytopathogen (Elzein et al. 2008, 2010). This supports its ability to persist and proliferate in substrate or soil for long periods, even beyond the completion of a particular S. hermonthica biocontrol season (Ciotola et al. 1995; Sauerborn et al. 1996), although without underrating the importance of site-specific factors (i.e., soil physicochemical properties and climatic conditions) (Zimmermann et al. 2016b).

\section{B. subtilis counteracted the fungal activity against S. hermonthica attachment}

B. subtilis (GB03) did not prevent the attachment of the sampled $S$. hermonthica. This outcome was not in agreement with the observations of Mounde et al. (2015), in which they reported GB03 suppressive activity toward S. hermonthica attachment, through reduction of Striga germination and haustorial attachment, including tubercle death. It is uncertain if this disaccord was also due to a possible inconsistency of GB03 effectiveness against differing $S$. hermonthica populations (as existent with Fos isolates), especially going by GB03 effectiveness against a Malian (West African) S. hermonthica population used by Mounde et al. (2015), whereas our study was based on an Ethiopian (East African) $S$. hermonthica population.

Furthermore, integration of GB03 with fungal treatments (FK3, Foxy-2, IMB12098) counteracted their activity against $S$. hermonthica attachment. This resulted in an undesirable promotion of $S$. hermonthica attachment, in the order of the suppressive tendency of the applied fungal treatments toward $S$. hermonthica: FK3 < Foxy-2 < IMB12098. This fungal counteractivity by GB03 could be explained by potential fungal

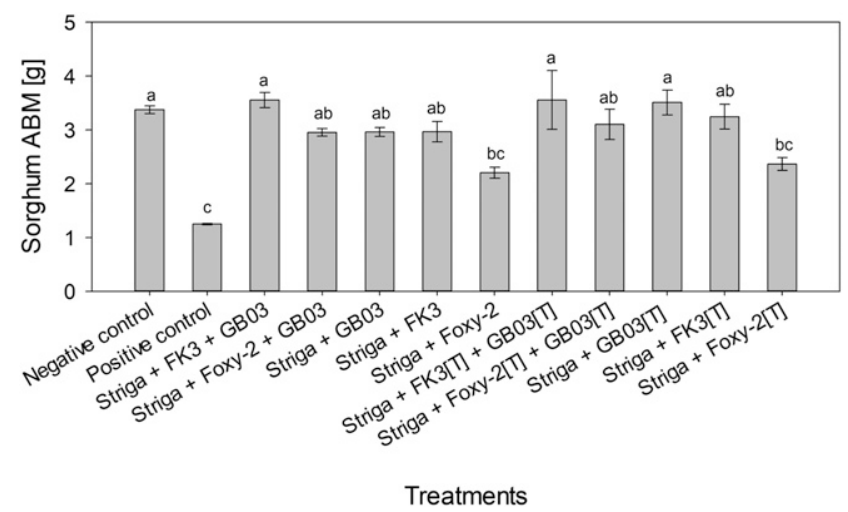

FIGURE 7

Tukey's range test for sorghum aboveground dry biomass (sorghum ABM [g]) response to post-Striga attachment application of wild-type and transformed (indicated with [T]) microbial treatments. Negative control $=$ sorghum $+\mathrm{dd}_{2} \mathrm{O}$ without Striga hermonthica. Positive control $=$ sorghum $+d_{d d H_{2}} \mathrm{O}$ with $\mathrm{S}$. hermonthica. Bars having at least a letter in common represent treatments means that are not significantly different $(\alpha=0.05)$. Error bars indicate standard error. 
antagonizing substances released by $B$. subtilis. Generally, PGPR secrete extracellular metabolites in the form of lytic enzymes, lipopeptides, and hydrogen cyanide, which can antagonize a variety of fungi and other phytopathogens (Beneduzi et al. 2012; Goswami et al. 2016). For instance, B. subtilis produces a bioactive metabolite, bacillaene, a polyene polyketide that confers antifungal activity against the genera Fusarium sp. and Trichoderma sp. (Um et al. 2013). Other B. subtilis metabolites, such as bacillomycin D, macrolactins, iturin, and fengycin, are also important antagonists to F. oxysporum (Caulier et al. 2019; Cawoy et al. 2015; Yuan et al. 2012). This, however, does not imply that in field conditions or natural ecologies Fos will be easily subdued (and restrained from controlling S. hermonthica) by $B$. subtilis or other comparable members of the soil microbiota. It was recently shown that apart from Fos being a naturally occurring, soil-borne phytopathogen with a successful biocontrol record against $S$. hermonthica in various agroecosystems, it is also compatible with indigenous maize rhizosphere microbiota, which include prokaryotic and fungal communities (Musyoki et al. 2016; Zimmermann et al. 2016a).

Cyan fluorescence detection revealed high GB03 localization in flavonoid-abundant spots of $S$. hermonthica shoot tissue. Typically, Striga spp. are rich in a variety of flavones (Hiremath et al. 1997; Kim et al. 2010; Nakanishi et al. 1985), and at 470 to $525 \mathrm{~nm}$, flavonoids emit in the blue or cyan region of the visible spectrum (Müller et al. 2013; Roshchina 2012). Flavonoids are important signaling compounds for initiating plant-microbe interactions (Straney et al. 2002). For instance, it stimulates Fusarium solani macroconidia germination (Ruan et al. 1995), it is a carbon source for some bacteria (Hassan and Mathesius 2012), and it acts as a chemo-attractant for symbiotic rhizobacterial interaction with plants (Steinkellner and Mammerler 2007). Microbial recognition of $S$. hermonthica characteristic flavonoids (and/or other specific metabolites) may explain the
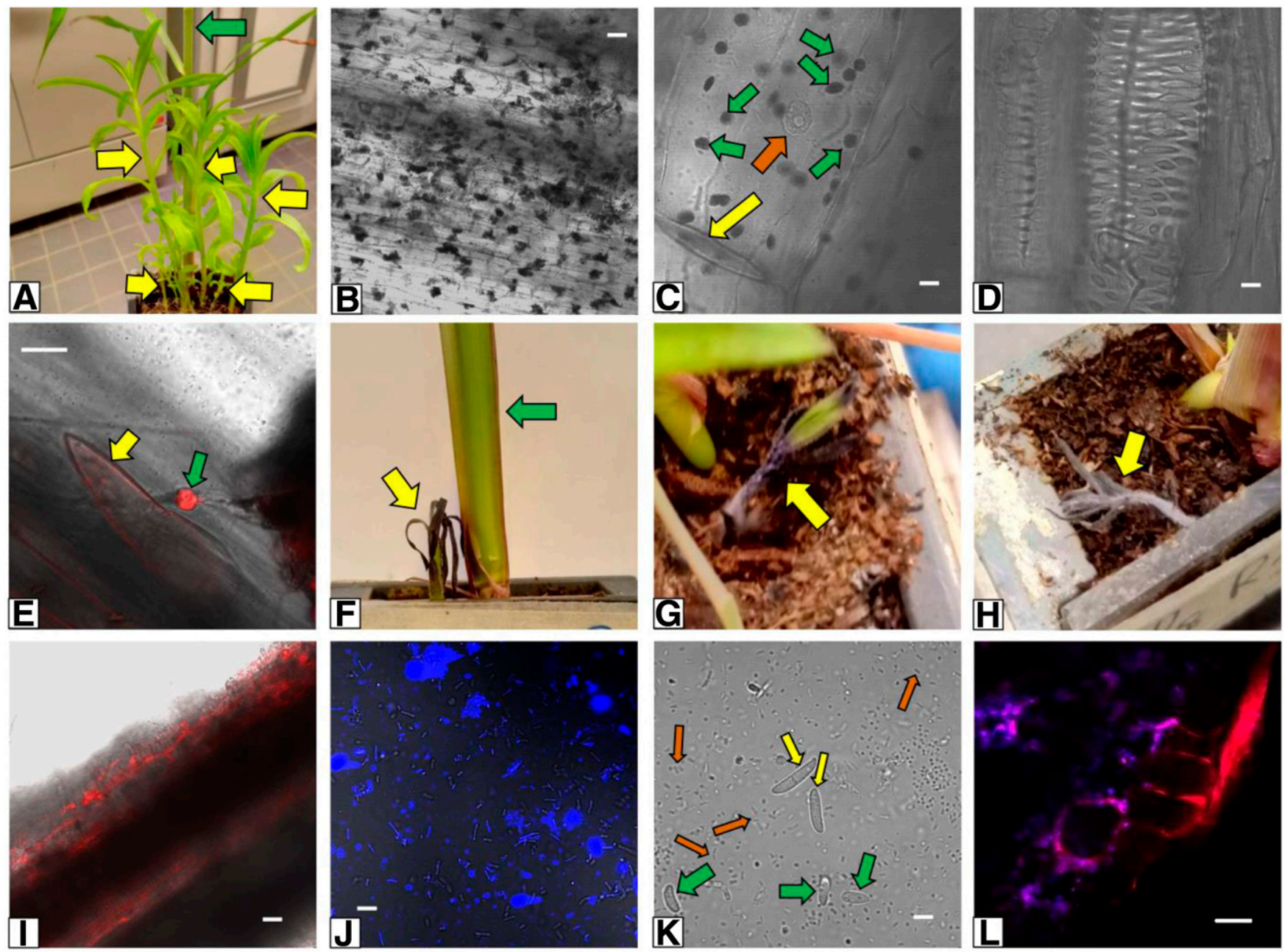

FIGURE 8

A, Healthy Striga hermonthica plants (yellow arrows) parasitizing sorghum (green arrow) in the positive control rhizobox. B, Healthy $S$. hermonthica leaf from the positive control showing chloroplasts (numerous dark spots). C, Sieve plate of sieve tube element (yellow arrow), chloroplasts (green arrows), and a companion cell nucleus (brown arrow) of healthy $S$. hermonthica phloem from the positive control. D, Reticulate vessel of noninfected S. hermonthica xylem from the positive control. E, A germinating FK3 chlamydospore (green arrow), with its germ tube penetrating the $S$. hermonthica trichome (yellow arrow). F, FK3-infected $S$. hermonthica (yellow arrow), parasitizing sorghum (green arrow). G, FK3 colonizing diseased S. hermonthica shoot (yellow arrow). H, Dead and degrading S. hermonthica plant (yellow arrow) completely colonized by FK3. I, Transformed FK3 expressing red fluorescence in diseased, necrotic, and decaying S. hermonthica tissue. J, Transformed GB03 expressing cyan fluorescence within shoot tissue of diseased S. hermonthica (ubiquitous autofluorescence is due to flavonoids). K, Consortia of FK3 macroconidia (yellow arrows), FK3 microconidia (green arrows), and short chains of GB03 (brown arrows) colocalizing in a diseased S. hermonthica shoot. L, Transformed FK3 hyphae and transformed GB03 occupying a common ecological niche of degrading S. hermonthica shoot tissue. Scale bars are $20 \mu \mathrm{m}$. 
attraction/infection of FK3 and GB03, in colocalizing $S$. hermonthica shoot tissue.

\section{T. viride was not effective against the sampled S. hermonthica}

T. viride (IMB12098) was initially included among the microbial treatments of the pre-Striga seed conditioning treatment application study, to serve as a reference to the investigated treatments. The decision was taken based on reports of the $S$. hermonthica seed germination inhibition activity of Trichoderma spp. For instance, Hassan et al. (2013) had reported T. viride of $10^{6}$ spore/ml concentration to completely inhibit $S$. hermonthica germination $(0 \%)$, but it enhanced $S$. hermonthica germination $(90 \%)$ compared with their control $(85 \%)$ at $10^{1}$ spore $/ \mathrm{ml}$. In our study, a slightly higher $T$. viride concentration of $10^{7} \mathrm{CFU} / \mathrm{ml}$ was used; nonetheless, it was not effective in controlling $S$. hermonthica germination and attachment. It could be speculated that this nonconformity of $T$. viride suppressive activity against $S$. hermonthica, as revealed by Hassan et al. (2013), was due to a different strain of $T$. viride used in their study. Alternatively, it may be ascribable to the different $S$. hermonthica population from Sinnar State (Sudan) used by Hassan et al. (2013), which was susceptible to $T$. viride, whereas our $S$. hermonthica from Sirinka (Ethiopia) was resistant to $T$. viride. The reason for the nonconformity remained unclear.

\section{CONCLUSIONS}

Despite the colocalization of Fos and GB03 in infected $S$. hermonthica shoots, the combined BCA treatment did not result in a stronger $S$. hermonthica control compared with the single FK3 treatment. The sampled $S$. hermonthica maintained its selective susceptibility to FK3 but not to Foxy-2. This variable susceptibility of $S$. hermonthica was perhaps also responsible for the inconsistent effectiveness of other acclaimed $S$. hermonthica BCAs (e.g., $B$. subtilis and $T$. viride) against our differing $S$. hermonthica population. Hence, prior to any $S$. hermonthica biocontrol program, a BCA strain/isolate confirmed for its effectiveness against a particular S. hermonthica population should be adhered to. This is clearly preferable, rather than applying a combination of contrasting BCAs, for which knowledge of their interaction or awareness on the susceptibility pattern of the $S$. hermonthica population toward the BCA is unknown or insufficient.

The effectiveness of a specific Fos isolate (i.e., FK3) against the sampled $S$. hermonthica was shown to be unaffected with changing Fos treatment application period during planting (i.e., pre-Striga seed conditioning or post-Striga attachment). Nevertheless, it is suggested to apply the BCA pre-Striga seed conditioning, because this would prevent $S$. hermonthica from infecting the host crop in the first place. Most times, the physiological damage initiated to the host crop by $S$. hermonthica could be irreversible (Beed et al. 2007; Rumsey 2012). Thus, exometabolites that specifically inhibit germination of $S$. hermonthica seeds, and/or haustoria development with attachment, shall be identified and validated from potent BCAs of $S$. hermonthica through tracer-assisted metabolomic techniques such as stable isotopy, positron emission tomography, nuclear magnetic resonance, and liquid/gas chromatography-mass spectrometry (Jang et al. 2018; Lin and Chung 2014). This could lead to the discovery of ecologically safe, specific metabolites, with stronger and broader efficacy range against diverse $S$. hermonthica populations.

Lastly, the discovery from this study, involving a phyllospheretransmitting, direct $S$. hermonthica infection by Fos through trichome entry, offers an alternative entry point. This is an addition to the recognized, rhizosphere-transmitting, indirect infection mechanism through the "sorghum central cylinder- $S$. hermonthica haustorial" connecting tissues within sorghum root (Elzein et al. 2010; Ndambi et al. 2011). This revelation paves the way for further research possibilities that center on exploiting this newly identified anatomical pathway for better $S$. hermonthica biocontrol. For instance, the induction of Fos sporal germination by particular $S$. hermonthica secondary metabolites can be further investigated through molecular identification and characterization of transcription factors with regulatory constituents by which a potent, $S$. hermonthica-attacking microbial strain specifically recognizes its host.

\section{ACKNOWLEDGMENTS}

The publication is an output of a Ph.D. scholarship at the University of Hohenheim in the framework of the project German-Ethiopian SDG Graduate School: Climate Change Effects on Food Security (CLIFOOD) between the Food Security Centre, University of Hohenheim (Germany) and the Hawassa University (Ethiopia), supported by the German Academic Exchange Service (DAAD) with funds from the German Federal Ministry for Economic Cooperation and Development (BMZ).

We thank the following individuals for their kind assistance in this study: Prof. Mark Farman (University of Kentucky, Lexington, KY) for providing the plasmids pFPL-Ch (61647) and pFPL-Rh (61649) through Addgene repository; Dr. Daniel R. Zeigler (Bacillus Genetic Stock Center, Columbus, OH) for providing Bacillus subtilis GB03 isolate; Dr. Charles I. Nwankwo (University of Hohenheim, Stuttgart, Germany) for sorghum seeds; Mr. Tamirat Tesfaye Abegaz (Sirinka Agricultural Research Centre [SARC], Sirinka, Ethiopia) and Dr. Gashaw Meteke (Hawassa University, Hawassa, Ethiopia) for Striga hermonthica seeds; and Mrs. Barbara Kaufmann, (University of Hohenheim, Stuttgart, Germany) for technical support during fluorescence microscopic analyses.

Author contributions: W. O. Anteyi designed and performed the experiments, collected, and analyzed the data, and prepared the manuscript. F. Rasche conceived of the study, supervised the work, critically reviewed the manuscript draft, and gave final approval of the published version.

\section{LITERATURE CITED}

Abbasher, A. A., Hess, D. E., and Sauerborn, J. 1998. Fungal pathogens for biological control of Striga hermonthica on sorghum and pearl millet in West Africa. Afr. Crop Sci. J. 6:179-188.

Abbasher, A. A., and Sauerborn, J. 1992. Fusarium nygamai, a potential bioherbicide for Striga hermonthica control in sorghum. Biol. Control 2: 291-296.

Addgene. 2019. Molecular biology reference: Antibiotics commonly used for plasmid selection. http://www.addgene.org/mol-bio-reference/.

Ahonsi, M. O., Berner, D. K., Emechebe, A. M., and Lagoke, S. T. 2002 Selection of rhizobacterial strains for suppression of germination of Striga hermonthica (Del.) Benth. seeds. Biol. Control 24:143-152.

Andargie, M., and Li, J. 2016. Arabidopsis thaliana: A model host plant to study plant-pathogen interaction using rice false smut isolates of Ustilaginoidea virens. Front. Plant Sci. 7:192.

Anteyi, W. O., and Rasche, F. 2020. Population genetic structure and markertrait associations in East and West African Striga hermonthica with varying phenotypic response to Fusarium oxysporum $\mathrm{f}$. sp. strigae isolates Foxy-2 and FK3. Plant J. doi.org/10.1111/tpj.14930.

Atera, E. A., Itoh, K., and Onyango, J. C. 2011. Evaluation of ecologies and severity of Striga weed on rice in sub-Saharan Africa. Agric. Biol. J. N. Am. 2:752-760.

Avedi, E. K., Ochieno, D. M. W., Ajanga, S., Wanyama, C., Wainwright, H., Elzein, A., and Beed, F. D. 2014. Fusarium oxysporum f. sp. strigae strain Foxy 2 did not achieve biological control of Striga hermonthica parasitizing maize in western Kenya. Biol. Control 77:7-14.

Backer, R., Rokem, J. S., Ilangumaran, G., Lamont, J., Praslickova, D., Ricci, E., Subramanian, S., and Smith, D. L. 2018. Plant growth-promoting rhizobacteria: Context, mechanisms of action, and roadmap to commercialization of biostimulants for sustainable agriculture. Front. Plant Sci. 9: 1473. 
Baiyegunhi, L. J. S., Hassan, M. B., and Ortmann, G. F. 2018. Impact of integrated Striga management (ISM) technology on maize productivity in northern Nigeria: A treatment effect approach. Afr. J. Sci. Technol. Innov. Dev. 10:335-344

Beed, F., Elzein, A., and Wainwright, H. 2013. Biocontrol of Striga-A progress report. Haustorium 64:7-8.

Beed, F. D., Hallett, S. G., Venne, J., and Watson, A. K. 2007. Biocontrol using Fusarium oxysporum; a critical component of integrated Striga management. Pages 283-300 in: Integrating New Technologies for Striga Control: Towards Ending the Witch-hunt. G. Ejeta and J. Gressel, eds. World Scientific, Singapore.

Beneduzi, A., Ambrosini, A., and Passaglia, L. M. P. 2012. Plant growthpromoting rhizobacteria (PGPR): Their potential as antagonists and biocontrol agents. Genet. Mol. Biol. 35:1044-1051.

Berner, D., Carsky, R., Dashiell, K., Kling, J., and Manyong, V. 1996. A land management-based approach to integrated Striga hermonthica control in sub-Saharan Africa. Outlook Agric. 25:157-164.

CABI. 2019. Striga hermonthica (witchweed). Invasive Species Compendium. CAB International, Wallingford, U.K. https://www.cabi.org/isc/ datasheet/51849.

Calo, L., Garcia, I., Gotor, C., and Romero, L. C. 2006. Leaf hairs influence phytopathogenic fungus infection and confer an increased resistance when expressing a Trichoderma $\alpha-1,3$-glucanase. J. Exp. Bot. 57: 3911-3920.

Caulier, S., Nannan, C., Gillis, A., Licciardi, F., Bragard, C., and Mahillon, J. 2019. Overview of the antimicrobial compounds produced by members of the Bacillus subtilis group. Front. Microbiol. 10:302.

Cawoy, H., Debois, D., Franzil, L., De Pauw, E., Thonart, P., and Ongena, M. 2015. Lipopeptides as main ingredients for inhibition of fungal phytopathogens by Bacillus subtilis/amyloliquefaciens. Microb. Biotechnol. 8: 281-295.

Ciotola, M., Watson, A. K., and Hallett, S. G. 1995. Discovery of an isolate of Fusarium oxysporum with potential to control Striga hermonthica in Africa. Weed Res. 35:303-309.

Dawud, M. 2017. Striga resistance in cereal crops: Recent progress and future prospects. A review. Global J. Sci. Front. Res. 17(3-D). https:// journalofscience.org/index.php/GJSFR/article/view/2007.

Elzein, A., Heller, A., Ndambi, B., De Mol, M., Kroschel, J., and Cadisch, G. 2010. Cytological investigations on colonization of sorghum roots by the mycoherbicide Fusarium oxysporum f. sp. strigae and its implications for Striga control using a seed treatment delivery system. Biol. Control 53: 249-257.

Elzein, A., and Kroschel, J. 2004. Fusarium oxysporum Foxy 2 shows potential to control both Striga hermonthica and S. asiatica. Weed Res. 44: 433-438.

Elzein, A., Kroschel, J., and Cadisch, G. 2008. Efficacy of Pesta granular formulation of Striga-mycoherbicide Fusarium oxysporum f. sp. strigae Foxy 2 after 5-year of storage. J. Plant Dis. Prot. 115:259-262.

Gong, X., Hurtado, O., Wang, B., Yi, M., Giraldo, M., Wu, C., Valent, B., Goodin, M. M., and Farman, M. 2015. pFPL vectors for high-throughput protein localization in fungi: Detecting cytoplasmic accumulation of putative effector proteins. Mol. Plant-Microbe Interact. 28:107-121.

Goswami, D., Thakker, J. N., and Dhandhukia, P. C. 2016. Portraying mechanics of plant growth promoting rhizobacteria (PGPR): A review. Cogent Food Agric. 2:1127500.

Hassan, M. M., Daffalla, H. M., Modwi, H. I., Osman, M. G., Ahmed, I. I., Abdel Gani, M. E., and Babiker, A. E. G. E. 2013. Effects of fungal strains on seeds germination of millet and Striga hermonthica. Univers. J. Agric. Res. 2:83-88

Hassan, M. M., Gani, M. E. S. A., and Babiker, A. G. E. T. 2009. Management of Striga hermonthica in sorghum using soil rhizosphere bacteria and host plant resistance. Int. J. Agric. Biol. 11:367-373.

Hassan, S., and Mathesius, U. 2012. The role of flavonoids in rootrhizosphere signalling: Opportunities and challenges for improving plant-microbe interactions. J. Exp. Bot. 63:3429-3444.

Hiremath, S. P., Badami, S., Swamy, H. K., Patil, S. B., and Londonkar, R. L. 1997. Antiandrogenic effect of Striga orobanchioides. J. Ethnopharmacol. 56:55-60.

Huchelmann, A., Boutry, M., and Hachez, C. 2017. Plant glandular trichomes: Natural cell factories of high biotechnological interest. Plant Physiol. 175:6-22.

iGEM, 2014. Transformation of Bacillus subtilis. International Genetically Engineered Machine. http://2014.igem.org/wiki/images/c/c2/LMU_Munich14_ Transformation_of Bacillus subtilis.pdf.

Jang, C., Chen, L., and Rabinowitz, J. D. 2018. Metabolomics and isotope tracing. Cell 173:822-837.

Kangethe, D., Wanyama, C., Ajanga, S., and Wainwright, H. 2016. Striga hermonthica reduction using Fusarium oxysporum in Kenya. Afr. J. Agric. Res. 11:1056-1061.
Kim, H., Kim, D., and Jang, Y. 2010. Phytochemical analysis of Striga hermonthica by DART-MS and HPLC-MS. Planta Med. 76:P217.

Kim, K. W. 2019. Plant trichomes as microbial habitats and infection sites. Eur. J. Plant Pathol. 154:157-169.

Kroschel, J., Hundt, A., Abbasher, A. A., and Sauerborn, J. 1996. Pathogenicity of fungi collected in northern Ghana to Striga hermonthica. Weed Res. 36:515-520.

Lin, G., and Chung, Y. L. 2014. Current opportunities and challenges of magnetic resonance spectroscopy, positron emission tomography, and mass spectrometry imaging for mapping cancer metabolism in vivo. BioMed Res. Int. 2014:625095.

Lugtenberg, B., and Kamilova, F. 2009. Plant-growth-promoting rhizobacteria. Annu. Rev. Microbiol. 63:541-556.

Mariutto, M., and Ongena, M. 2015. Molecular patterns of rhizobacteria involved in plant immunity elicitation. Pages 21-56 in: Plant Microbe Interactions: Advances in Botanical Research, Vol. 75. H. Bais and J. Sherrier, eds. Elsevier, Amsterdam, the Netherlands.

Marley, P. S., Ahmed, S. M., Shebayan, J. A. Y., and Lagoke, S. T. O. 1999. Isolation of Fusarium oxysporum with potential for biocontrol of the witchweed (Striga hermonthica) in the Nigerian Savanna. Biocontrol Sci. Technol. 9:159-163.

Massart, S., Perazzolli, M., Höfte, M., Pertot, I., and Jijakli, M. H. 2015. Impact of the omic technologies for understanding the modes of action of biological control agents against plant pathogens. BioControl 60: $725-746$

Miché, L., Bouillant, M. L., Rohr, R., Sallé, G., and Bally, R. 2000. Physiological and cytological studies on the inhibition of Striga seed germination by the plant growth-promoting bacterium. Eur. J. Plant Pathol. 106:347-351.

Moore, D., Robson, G. D., and Trinci, A. P. J. 2018. Necrotrophic and biotrophic pathogens of plants. Section 14.10 in: 21st Century Guidebook to Fungi, 2nd Ed., online version. http://www.davidmoore.org.uk/21st_ Century_Guidebook to Fungi_PLATINUM/Ch14 10.htm.

Mounde, L. G., Anteyi, W. O., and Rasche, F. 2020. Tripartite interaction between Striga spp., cereals, and plant root-associated microorganisms: A review. CAB Rev. 15:005.

Mounde, L. G., Boh, M. Y., Cotter, M., and Rasche, F. 2015. Potential of rhizobacteria for promoting sorghum growth and suppressing Striga hermonthica development. J. Plant Dis. Prot. 122:100-106.

Müller, S. M., Galliardt, H., Schneider, J., Barisas, B. G., and Seidel, T. 2013. Quantification of Förster resonance energy transfer by monitoring sensitized emission in living plant cells. Front. Plant Sci. 4:413.

Musyoki, M. K., Cadisch, G., Zimmermann, J., Wainwright, H., Beed, F., and Rasche, F. 2016. Soil properties, seasonality and crop growth stage exert a stronger effect on rhizosphere prokaryotes than the fungal biocontrol agent Fusarium oxysporum f. sp. strigae. Appl. Soil Ecol. 105:126-136.

Nakanishi, T., Ogaki, J., Inada, A., Murata, H., Nishi, M., Iinuma, M., and Yoneda, K. 1985. Flavonoids of Striga asiatica. J. Nat. Prod. 48:491-493.

Ndambi, B., Cadisch, G., Elzein, A., and Heller, A. 2011. Colonization and control of Striga hermonthica by Fusarium oxysporum f. sp. strigae, a mycoherbicide component: An anatomical study. Biol. Control 58: $149-159$

Nzioki, H. S., Oyosi, F., Morris, C. E., Kaya, E., Pilgeram, A. L., Baker, C. S., and Sands, D. C. 2016. Striga biocontrol on a toothpick: A readily deployable and inexpensive method for smallholder farmers. Front. Plant Sci. 7:1121.

Roshchina, V. V. 2012. Vital autofluorescence: Application to the study of plant living cells. Int. J. Spectrosc. 2012:1-14.

Ruan, Y., Kotraiah, V., and Straney, D. C. 1995. Flavonoids stimulate spore germination in Fusarium solani pathogenic on legumes in a manner sensitive to inhibitors of cAMP-dependent protein kinase. Mol. PlantMicrobe Interact. 8:929-938.

Rumsey, A. 2012. Stopping Striga before it's started. CABI: The plantwise blog. https://blog.plantwise.org/2012/01/17/stopping-striga-beforeits-started/.

Sauerborn, J., Abbasher, A. A., Kroschel, J., Cornes, D. W., Zoschke, A., and Hine, K. T. 1996. Striga hermonthica control with Fusarium nygamai in maize. Pages 461-466 in: Proceedings of the IX International Symposium on Biological Control of Weeds, 19-26 January. V. C. Moran and J. H. Hoffmann, eds. University of Cape Town, Stellenbosch, South Africa.

Schaub, B., Marley, P., Elzein, A., and Kroschel, J. 2006. Field evaluation of an integrated Striga hermonthica management in sub-Saharan Africa: Synergy between Striga-mycoherbicides (biocontrol) and sorghum and maize resistant varieties. J. Plant Dis. Prot. 20:691-699.

Sibhatu, B. 2016. Review on Striga weed management. Int. J. Life Sci. Sci. Res. 2:110-120.

Steinkellner, S., and Mammerler, R. 2007. Effect of flavonoids on the development of Fusarium oxysporum f. sp. lycopersici. J. Plant Interact. 2: $17-23$ 
Straney, D., Khan, R., Tan, R., and Bagga, S. 2002. Host recognition by pathogenic fungi through plant flavonoids. Pages 9-22 in: Flavonoids in Cell Function.B. S. Buslig and J. A. Manthey, eds. Springer, Boston, MA.

Sugimoto, Y., Ahmed, N. E., Yasuda, N., and Inanaga, S. 2002. Trichothecene inhibitors of Striga hermonthica germination produced by Fusarium solani. Weed Sci. 50:658-661.

Teka, H. B. 2014. Advance research on Striga control: A review. Afr. J. Plant Sci. 8:492-506.

Um, S., Fraimout, A., Sapountzis, P., Oh, D.-C., and Poulsen, M. 2013. The fungus-growing termite Macrotermes natalensis harbors bacillaeneproducing Bacillus sp. that inhibit potentially antagonistic fungi. Sci. Rep. 3:3250.

Velivelli, S. L., De Vos, P., Kromann, P., Declerck, S., and Prestwich, B. D. 2014. Biological control agents: From field to market, problems, and challenges. Trends Biotechnol. 32:493-496.

Venne, J., Beed, F., Avocanh, A., and Watson, A. 2009. Integrating Fusarium oxysporum f. sp. strigae into cereal cropping systems in Africa. Pest Manag. Sci. 65:572-580.

Werker, E. 2000. Trichome diversity and development. Pages 1-35 in: Advances in Botanical Research Incorporating Advances in Plant Pathology, Vol. 31: Plant Trichomes. J. A. Callow, D. L. Hallahan, and J. C. Gray, eds. Academic Press, San Diego, CA.

Xiang, H., Yao, R., Quan, T., Wang, F., Chen, L., Du, X., Zhang, W., Deng, H., Xie, D., and Luo, T. 2017. Simple $\beta$-lactones are potent irreversible antagonists for strigolactone receptors. Cell Res. 27: 1525-1528.
Yonli, D., Traore, H., Sereme, P., Hess, D. E., and Sankara, P. 2010 Pathogenicity of Fusarium isolates to Striga hermonthica in Burkina Faso. Pak. J. Biol. Sci. 13:201-208.

Yoshida, S., Forno, D. A., Cook, J. H., and Gomez, K. A. 1976. Pages 61-66 in: Laboratory Manual for Physiological Studies of Rice, 3rd Ed. International Rice Research Institute, Laguna, Philippines.

Yuan, J., Li, B., Zhang, N., Waseem, R., Shen, Q., and Huang, Q. 2012. Production of bacillomycin- and macrolactin-type antibiotics by Bacillus amyloliquefaciens NJN-6 for suppressing soilborne plant pathogens. J. Agric. Food Chem. 60:2976-2981.

Zhang, W., Zhao, W., Huang, J., Feng, J., Yan, H., Yang, L., Li, X., and Yan, J. 2014. PEG-mediated genetic transformation of Fusarium oxysporum $\mathrm{f}$ sp. conglutinans to study pathogenesis in cabbage. Chiang Mai J. Sci. 41: 945-956.

Zimmermann, J., Musyoki, M. K., Cadisch, G., and Rasche, F. 2016a Biocontrol agent Fusarium oxysporum f. sp. strigae has no adverse effect on indigenous total fungal communities and specific AMF taxa in contrasting maize rhizospheres. Fungal Ecol. 23:1-10.

Zimmermann, J., Musyoki, M. K., Cadisch, G., and Rasche, F. 2016b. Proliferation of the biocontrol agent Fusarium oxysporum f. sp. strigae and its impact on indigenous rhizosphere fungal communities in maize under different agro-ecologies. Rhizosphere 1:17-25.

Zonno, M. C., Vurro, M., Capasso, R., Evidente, A., Cutignano, A., Sauerborn, J., and Thomas, H. 1996. Phytotoxin metabolites produce by Fusarium nygamai from Striga hermonthica. Pages 223-226 in: Proceedings of the 9th International Symposium on Biological Control of Weeds, Jan. 19-26, University of Cape Town, South Africa. 